\title{
Sorgulama Temelli Öğrenme Yönteminin Öğrencilerin 21. Yüzyıl Becerilerine ve Yansıtıcı Düşünme Düzeylerine Etkisi', 2
}

\author{
(iD) Şadiye KARAŞAH ÇAKICI \\ Ondokuz Mayıs Üniversitesi \\ karasah08sados@gmail.com \\ Mehmet YAKIŞAN \\ Ondokuz Mayıs Üniversitesi \\ yakisan@omu.edu.tr
}

Gönderilme Tarihi: 08/09/2020

Kabul Tarihi: $26 / 11 / 2020$

Yayınlanma Tarihi: 30/11/2020

DOI: $\underline{10.30855 / \text { gjes.2020.06.03.005 }}$

\begin{tabular}{l}
\hline Makale Bilgileri \\
\hline Anahtar Kelimeler: \\
21. yüzyıl becerileri \\
Yansıtııı düşünme \\
düzeyi, \\
Sorgulama temelli \\
öğrenme, \\
Biyoloji eğitimi
\end{tabular}

\begin{abstract}
ÖZET
İnsanda dolaşım sistemi kavramının öğrenciler tarafından zihinlerinde doğru bir şekilde yapılandırılması gerekmektedir. Bu amaç doğrultusun da biyoloji eğitiminde farklı öğretim yöntem ve tekniklerinden yararlanılarak ilgili eğitim süreci yönetilmelidir. Bu farklı yöntem ve teknikler sayesinde her öğrenci zihinlerinde bilgiyi işler ve doğru şekilde algılayıp kalıcılığını artırabilir. Bu çalışma günümüzde biyoloji eğitiminde zamanla kullanımı artan sorgulama temelli öğrenme yöntemi üzerine yapılmıştır. Araştırmada, sorgulama temelli öğrenme yöntemine göre dolaşım sistemi konusunda hazırlanan etkinliklerin 11. sınıf öğrencilerinin cinsiyetleri açısından 21. yüzyıl becerilerine ve yansıtıcı düşünme düzeyilerine yönelik etkisi incelenmiştir. Araştırmada, öğrencilerin 21. yüzyıl becerilerini ve yansıtıcı düşünme düzeylerini tespit etmek için; '21. Yüzyıl Beceri Ölçeği', 'Stem'e Karşı Tutum Ölçeği' 21. Yüzyıl alt boyut ölçeği ve 'Yansıtıcı Düşünme Düzeyi Belirleme' ölçekleri kullanılmıştır. Bu ölçekler öntest ve son test olmak hem kız öğrencilere hem de erkek öğrencilere uygulanmıştır. 2016-2017 yılı bahar döneminde Samsun ili İlkadım ilçesinde bulunan bir Anadolu lisesinde 11. sınıf kız ve erkek öğrencileriyle birlikte yürütülmüştür. Araştırmaya kız öğrenci grubundan 24 öğrenci, erkek öğrenci grubundan ise 21 olmak üzere toplam 45 öğrenci dahil edilmiştir. Uygulama sonrasında elde edilen veriler SPSS.21 istatistik programı kullanılarak analiz edilmiştir. Analiz sonucunda elde edilen bulgulara göre ön testten elde edilen verilerde cinsiyet açısından öğrenciler arasında anlamlı fark bulunmamaktadır. Ancak sontestten sonrasında elde edilen verilerde erkek öğrenci grubundaki öğrencilerin her üç ölçekten aldıkları puanların kız grubundaki öğrencilerin puanlarına göre erkek öğrenciler lehine anlamlı farklılık tespit edilmiştir.
\end{abstract}

\footnotetext{
${ }^{1} \mathrm{Bu}$ araştırma Uluslararası 100. Yıl Eğitim Sempozyumu'nda sözlü olarak sunulan bildiri genişletilerek hazırlanmıştır.

$2 \mathrm{Bu}$ araştırma Dr. Öğr. Üyesi Mehmet YAKIŞAN danışmanlığında yürütülen Şadiye KARAŞAH ÇAKICI'nın yüksek lisans tezinden üretilmiştir
}

Karaşah Çakıcı, Ş., \& Yakışan, M. (2020). Sorgulama temelli öğrenme yönteminin öğrencilerin 21. yüzyıl becerilerine ve yansıtıcı düşünme düzeylerine etkisi. Gazi Eğitim Bilimleri Dergisi, 6(3), 344360.

DOI: https://dx.doi.org/110.30855/gjes.2020.06.03.005

Dergi Web Sayfası: http://dergipark.gov.tr/gebd 


\section{The Effect of Inquiry Based Learning Method on Students' 21st Century Skills and Reflective Thinking Levels}

\begin{tabular}{ll}
\hline \hline Article Info & ABSTRACT \\
\hline Keywords: & The concept of the human circulatory system needs to be structured correctly by \\
Reflective thinking, & students in their minds. For this purpose, biology education should be managed by \\
Question-based & using different teaching and techniques. Thanks to these different methods and \\
learning, & techniques, each student can process information in their minds, perceive them \\
Biology education & correctly, and increase their permanence. This study has been conducted on the \\
inquiry-based learning method, which has been increasingly used in biology \\
education today. In the study, the effect of the activities prepared on the circulatory \\
system according to the inquiry-based learning method on the 21st-century skills and \\
reflective thinking levels of 11th-grade students in terms of gender was examined. In \\
the research, various scales were used to determine the 21st-century skills and \\
reflective thinking levels of the students. These scales; '21. Century Skill Scale "is the" \\
Attitude towards Stem Scale "is the 21st-century sub-dimension scale and" Reflective \\
Thinking Level Determination "Scale. These scales were applied to both female \\
students and male students as pre-test and post-test. It was conducted with 11th- \\
grade female and male students in Tülay Başaran Anatolian High School in Samsun \\
province's İlkadim district in the spring of 2016-2017. A total of 45 students, 24 from \\
the female student group and 21 from the male student group, were included in the \\
study. The data obtained after the application were analyzed using the SPSS.21 \\
statistical program. According to the findings obtained as a result of the analysis, \\
there is no significant difference between the students in terms of gender in the data \\
obtained after the first application. However, in the data obtained after the second \\
application, a significant difference was found for all three scales in the male student \\
group compared to the female students.
\end{tabular}

\section{GİRİ̧̧}

Bilim, teknolojinin ışığında hızla gelişmektedir. Bilimin gelişmesi ile birlikte teknoloji de hızına hız katmaktadır. Bilim ve teknolojinin gelişimi, ülkelerin hem ekonomik alanındaki değişimlerine hem de siyasi açıdan değişimlerine ciddi bir katkısı vardır. Ayrıca teknolojideki bu gelişim, bilimsel bilgiye erişimi kolaylaştırmakta ve yaratıcılığa katkı sağlamaktadır (Çakmak, 2008). İlerleyen teknoloji ve bilim faaliyetlerini takip edebilmek ve benimsemek adına fen eğitimine önem verilmelidir. $\mathrm{Bu}$ amaçla araştıran, sorgulayan, fen okuryazarı bireyler yetiştirilmelidir (Milli Eğitim Bakanlığı, 2017).

Milli Eğitim Bakanlığının yayımladığı eğitim programları çerçevesinde, fen eğitimi için temel stratejide araştıran ve sorgulayan bireyler yetiştirmek amaçlanmıştır. Sorgulayan birey, fen eğitimi açısından oldukça önemlidir. Sorgulama temelli öğrenme yöntemi; öğretimin merkezine öğrenciyi aldığından dolayı bireyin sadece akademik başarısına değil motivasyon, tutum ve beceri gibi çeşitli değişkenlerine de olumlu yönde etki edebilmektedir (Tüysüz, Şardağ ve Durukan, 2017). Bu araştırma, fen eğitiminin bir dalı olan biyoloji eğitimi üzerine yapılmıştır. Biyoloji dersinin temelinde, kendini ve yaşadığı doğal çevreyi tanıma vardır. Biyoloji dersinin amacı; bireyin doğal çevresine zarar vermeden, yaşamı süresince toplumla bir arada yaşayan 
bireyler yetiştirmektir (Ekici, 2001). Aynı zaman da birey biyoloji eğitimi ile kendini ve çevresini tanımakta ve kendi bedeninde olan reaksiyonları anlamaktadır. Biyoloji eğitimi müfredatında yer alan sistemler konusu bu çalışma da sorgulama temelli öğrenme yöntemi ile öğrencilere aktarılmıştır.

Sorgulama temelli öğretimi, geleneksel öğretimden ayıran noktalar vardır. Bu noktalar, öğrencilerin merak ederek bilgileri analiz etme ve zihinlerinde bilgiyi yapılandırarak gerçekleştirdikleri öğretim sürecidir (Karamustafaoğlu ve Havuz, 2016). Bir öğretim sürecinde, en önemli unsurlardan biri de öğrencidir. Yapılan her türlü etkinlik öğrencinin öğrenmesini amaçlamaktadır. Bu yönüyle iyi bir iletişim kurabilen, öğrenmeye hevesli, düşünen ve girişimci özelliklere sahip bir öğrenci; öğrenme için olumlu ve gerekli bir unsurdur (Ekşioğlu ve Güven, 2015). Sorgulama temelli öğrenme süreci fen eğitimi için önemlidir. Çünkü birey, Fen Bilimleri Dersi Öğretim Programı́nda da bahsedildiği üzere, tıpkı bilim insanı gibi hareket eder ve süreç içerisinde araştırma yaparak bilgiye ulaşmada aktif rol alır. Bundan dolayı öğrenci, bilgiye ulaşma yollarını iyi öğrenmelidir. Öğrenci sorgulama süreci içinde elde ettiği bilgileri, bilimsel bilgi ile bilimsel olmayan bilgi şeklinde ayırt edebilmelidir. Öğretmenin sorgulama sürecinde yeri oldukça önemlidir. Sorgulama sürecinde öğretmenler de doğru bilgi kaynakları hakkında bilgi vermeli, öğrencilerini iyi yönlendirmelidir ve öğrencilerine öğrenme alışkanlıkları kazandırmalıdır (Sarığlan ve Fatih, 2017). Sorgulama hangi düzeyde olursa olsun öğretmen sürecin içinde olmalıdır. Sorgulama temelli öğrenme düzeylerini bazı kurumlar tanımlamışlardır. Bunlardan biri olan INSE'ye (2000) göre Sorgulama temelli öğrenme; a) Öğretmen merkezli sorgulama, b) Klavuzlu araştırma sorgulama, c) Açık sorgulama olmak üzere üç düzeyde ele alınmıştır.

$\mathrm{Bu}$ düzeyler ayrıntılı şekilde incelendiğinde öğretmenin konumuna göre düzeylerin tanımlanmış olduğu anlaşılmaktadır. Öğretmen merkezli sorgulama da öğretmen soruyu belirler, süreci planlar ve uygulamayı gerçekleştirir. Klavuzlu sorgulama da ise öğretmen, soruları seçerken süreci öğrencisi ile birlikte planlar. Açık sorgulama da ise öğretmen gözlemler; öğrenciler soruları kendileri hazırlar ve süreci kendi planlar. Bu üç sorgulama düzeyinin kendi için de avantajları vardır. Öğretmen merkezli sorgulama tipinde birey zaman sıkıntı yaşamaz. Ancak bireyin araştırma becerileri de istenilen düzeyde gelişmez. Klavuzlu araştırma sorgulama düzenli bir şekilde ilerler ama yaratıcılık gelişmez. Açık sorgulamada ise araştırma becerileri ve yaratıcılık gelişirken zaman yönetiminde sıkıntı yaşanabilir (Llewellyn, 2005).

Bir eğitim programı sorgulama temelli öğrenme yöntemi ile yürütülürken bir dizi adım takip edilir. Bu yöntemde ilk önce öğrencinin kendini sorgulama isteği doğar. İstek duygusunun ardından sorgulanmak istenen kavramlarla ilgili ön bilgiler açı̆̆a çıkartılır. Ön bilgiler göz önüne alınarak bir hipotez oluşturulur ve hipotez için bir uygulama tasarlanır. En son olarak 
uygulamanın süreci planlanır ve elde edilen sonuçlar paylaşılır. Ülkemizde de Fen Bilimleri Dersi Öğretim Programında da araştırma ve sorgulama süreci ‘Öğrenme süreci; keşfetme, sorgulama, argüman oluşturma ve ürün tasarlamayı' kapsamaktadır. Ayrıca öğrencilerin kendilerini yazılı, sözlü ve görsel olarak ifade ederek iletişim ve yaratıcı düşünme becerilerinin geliştirilmesine imkân tanıyan fırsatların öğrencilere sunulması beklenmektedir. Öğrencilerin fikirlerini rahatça ifade edebilmeleri, düşüncelerini farklı gerekçelerle destekleyebilmeleri ve arkadaşlarının iddialarını çürütmek amacıyla karşıt argümanlar geliştirebilmeleri için bilimsel olgulara yönelik yarar-zarar ilişkisini tartışabilecekleri ortamlar sağlanmalıdır. Öğretmenler, 'öğrencilerinin geçerli verilere dayalı oluşturdukları iddiaları haklı gerekçelerle sundukları tartışmalarda yönlendirici ve rehber rolü üstlenir' şekilde ifade edilmiştir (MEB, 2018, s.11).

Sorgulama temelli öğrenme yönteminde, öğrenci sürecin başkahramanı olduğu için bir bilim insanı olarak hareket etmelidir. Bu durumdan dolayı öğrencinin bazı becerilere sahip olması gerekmektedir. Bu beceriler; verileri sınıflama, sosyal iletişim, yorumlama, zaman-mekân ilişkilerini kullanma, hipotez kurma, çalışmanın niceliklerini belirleme-kontrol etme, gözlem gücü, sonuca ulaşma, destekleyici düşünceleri bulma şeklinde sıralanabilir (Tan ve Temiz, 2003). $\mathrm{Bu}$ durum göz önüne alındığın da sorgulama temelli öğrenme yöntemi içinde bulunduğumuz yüzyılın becerilerini de destekler nitelikte oldukça kullanılan bir yöntemidir.

İçinde bulunduğumuz çağ bilgiye kolay bir şekilde ulaşabildiğimiz ve bilgi yığınının oldukça fazla olduğu bir dönemdir. Bu dönem içinde, bir bilgiye ulaşmak için bir dizi beceriye ihtiyaç vardır. Bu beceriler 21. Yüzyıl becerileri içerisinde tanımlanmıştır. 21. Yüzyıla ayak uydurabilmek amacıyla sahip olmamız gereken becerilerin kazanılmasın da eğitimden yararlanmalıyız. Zira eğitim sayesinde bireyler yaşanılan çă̆ın gerekliliklerini kazanacak ve gerekli bilgi ve beceriye sahip olacaktır. Colwill ve Gallagher'a (2007) göre eğitimin temel amaçlarından biri de 21. yüzyılın istekleri doğrultusunda bireyler yetiştirmektir. Eğitim bu istek üzerine ilerlemeli ve bireyleri, içinde bulunduğumuz çağa ayak uydurabilecek şekilde yetiştirmelidir. Günümüzde her birey kendi eğitimi için doğru bilgiyi bulmalı ve iyi değerlendirmelidir. 21. Yüzyıl becerilerinden bilgi, medya ve teknoloji okuryazarlığı bu noktada önemli bir yere sahiptir. Bilgi okuryazarlığı; bilgi patlamasının olduğu şu yüzyılda bireylerin akademik yaşam, iş hayatı gibi kurumlarda başarı elde edebilmek için doğru bilgi kaynağına ulaşması, istenilen şekle dönüştürmesi, sunması ve doğru bir şekilde değerlendirmesi şeklinde tanımlanabilir (Başaran, 2005). 21.yüzyılda karşımıza çıkan kavramlardan bir diğeri de teknoloji okuryazarlığıdır. “Teknoloji okuryazarlığı: teknolojiyi kullanma, anlama, yönetme ve değerlendirme becerilerinin tümüdür" şeklinde tanımlanabilir (International Technology Education Association, 2003). Medya okuryazarlı̆̆ı ise medyada karşılaşılan mesajların doğru çözümlenmesi ve açı veya derin olarak nitelendirilen mesajları fark edebilme şeklinde 
tanımlanabilir (Karakoyun, 2014). Yaşam ve kariyer becerileri; toplum için de yaşamasını kolaylaştırmak bireylerin küresel ortamda var olmalarını sağlayan, değişen yaşam koşullarına uyum sağlama gücü sağlayan becerilerdir (P21, 2015). Teknoloji hızla gelişmektedir, teknolojinin bu hızlı değişimi ile zaman da hızlı bir şekilde değişmektedir. Esneklik ve uyum becerisi ile değişen bu zamana ayak uydurmak ve geride kalmamak için bilgi üretebilen bireyler olmak için sahip olmamız gereken becerilerdir (Eryılmaz ve Ulusoy, 2015). Bu grubun başka bir becerisi ise özyönetimdir. Bilgi çağındaki tüm bireylerin sahip olması gereken bir beceridir. Kendini yönetme, her bireyin görev ve sorumlulukları yerine getirebilmesi için sahip olması zorunlu ve bu sebepten dolayı 21. yüzyıl becerileri arasında tanımlanmış bir beceridir (Kalyoncu, 2012). Sosyal beceriler ise kalabalık ortamlarda bulunduğumuz günümüzde çevremizle etkili bir etkileşim için sahip olmamız gereken bir beceridir. Sosyal becerileri çok iyi gelişmiş bireylerin, liderlik becerileri de paralel şekilde gelişim göstermektedir. Bir diğer 21. Yüzyıl becerisi ise liderliktir. Liderlik motivasyon kaybı, stres gibi olumsuz durumları görmezden gelerek değişime uyum sağlayan, özdenetimini güçlü kişilerdir. İyi bir lider mevcut tüm imkânları etkili şekilde kullanarak fırsatları başarıyla taçlandıran ve düşüncelerini eyleme dökebilen kişilerin bulundurduğu bir beceridir. Aynı zamanda sosyal çevresinde oluşan fikir ayrılıklarını uzlaşmayla çözümleyen, engelleri yeniliklere dönüştürebilen bireylerde lider kişilerin özelliklerindendir (P21, 2015).

Düşünme becerilerinden olan yaratıcı düşünme becerisine sahip olan bireyler karşılaştıkları problemlere duyarlı olurlar ve bu duyarlılığın yanında bu problemlere alternatif çözüm önerileri getirirler. Aynı zaman da bu kişiler alışılııııın dışında olup kimsenin fark etmediklerini fark ederler ve çözüm önerileri kendine özgüdür (Karakuş, 2011). Düşünme becerilerinden bir diğeri eleştirel düşünme becerisidir. Cüceloğlu (1995), eleştirel düşünmenin tanımını, ‘bireyin kendi zihnindeki bilincinde olduğu düşünme süreçlerini, başkalarının da düşünme aşamalarını göz önüne alarak, öğrenilebilenleri uygulamaya geçirerek etrafımızdaki olayları algılamamızı amaç edinen organize bir süreç' olarak tarif etmiştir. Üstünoğlu (2006) bir diğer düşünme becerilerinden olan yansıtıcı düşünmeyi, 'bireyin önce kendisinin sonra diğerlerinin bir konu ile ilgili ulaştıkları yargılara ön yargısız, düşüncelerini ifade etmekte zorlanmayan, etrafına açık davranma ve ileri görüşlülük' olarak tanımlamıştır. Bu ana başlığın başka bir becerisi ise problem çözme becerisidir. İnsanlar yaşamı boyunca birçok problem durumuyla karşılaşırlar ve bu problemlere bir çözüm önerisi getirmek zorundadırlar. Bu amaçla problem çözme becerisine sahip bireyler karşılarına çıkan bir sorunla öğrenilenin ötesine giderek yeni çözüm yolları bulmalıdırlar (Korkut, 2002).

Bu çalışmanın amacı; insanda dolaşım sistemi ve kan grupları ünitesinin öğretimi ile ilgili sorgulama temelli öğrenme yöntemine uygun olarak hazırlanan etkinliklerin, cinsiyet açısından, 
öğrencilerin 21. Yüzyıl becerilerine ve yansitıcı düşünme düzeylerine yönelik etkilerini incelemektir. Bu problem çerçevesinde alt problemler şu şekilde sıralanabilir;

1. Sorgulama temelli öğrenme yönteminine göre dolaşım sistemi ve kan grupları ünitesinin öğretimi için hazırlanan etkinliklere katılan 11. sınıf öğrencilerinin 21. yüzyıl becerileri cinsiyet açısından farklılaşmakta mıdır?

2. Sorgulama temelli öğrenme yönteminin göre dolaşım sistemi ve kan grupları ünitesinin öğretimi için hazırlanan etkinliklere katılan 11. sınıf öğrencilerin yansıtıcı düşünme düzeyleri cinsiyet açısından farklılaşmakta mıdır?

\section{YÖNTEM}

İnsanda dolaşım sistemi ve kan grupları ünitesinin öğretimi ile ilgili sorgulama temelli öğrenme yöntemine uygun olarak hazırlanan etkinliklerin, cinsiyet açısından, öğrencilerin 21. Yüzyıl becerilerine ve yansıtıcı düşünme düzeylerine yönelik etkilerinin incelendiği bu çalışma, deneysel yöntemden yararlanılarak yürütülmüştür. Deneysel desenlerden yarı deneysel desen kullanılmıştır. İlgili araştırma nicel olup, nicel araştırma modeli ölçülebilir türde veri elde etmeyi amaçlar ve elde edilen bu veriler istatistiksel analiz yöntemi ile yorumlanır (Çakıcl, 2007). Bu çalışma da, araştırma desenlerinden "ön test - son test tek gruplu deneysel desen" kullanılmıştır.

\section{Örneklem}

Çalışmanın örneklemini, 2016-2017 eğitim öğretim yılı ikinci döneminde, Samsun ilinde bulunan bir Anadolu lisesinde ki 11. sınıf öğrencileri oluşturmaktadır. Araştırma 11. sınıf öğrencilerinden 11-A ve 11-C sınıfındaki kız ve erkek öğrenciler dahil edilerek yürütülmüştür. Kız öğrenci grubundan 24 öğrenci, erkek öğrenci grubundan ise 21 olmak üzere toplam 45 öğrenci çalışmaya dahil edilmiştir.

\section{Veri Toplama Araçları}

Çalışmada veri toplama aracı olarak 3 farklı ölçek uygulanmıştır. Bu ölçekler; '21. Yüzyıl Beceri ölçeği', 'Stem'e Karşı Tutum Ölçeği'nin 21. Yüzyıl Yetenekleri alt boyutu ve 'Yansitıcı Düşünme Düzeyi Belirleme' Ölçeğidir.

21. yüzyıl beceri ölçeği olarak; Kang, Kim, Kim ve You (2012) tarafından geliştirilen ve Karakaş (2015) tarafından Türkçeye uyarlanan '21. Yüzyıl Becerileri Ölçeği' kullanılmıştır. Bu ölçek özgün biçiminde 33 madde bulunmaktadır. Bu maddeler üç ana boyuttan (bilişsel, duyuşsal ve sosyokültürel) ve 21 alt boyuttan oluşmaktadır. $5^{`}$ li likert tipinde olan ölçekte her bir ifadenin karşısında Kesinlikle Katılıyorum, Katılıyorum, Kararsızım, Katılmıyorum, Kesinlikle Katılmıorum şeklinde, öğrencilerin o ifade ile ilgili düşüncelerini yansıtabilecekleri cevaplar bulunmaktadır. Ölçek Türkçeye uyarlandıktan sonra doğrulayıcı faktör analizi yapılmış ve analiz 
sonucunda 32 maddenin toplam üç alt boyutta toplandığı sonucuna ulaşılmıştır. Aynı zamanda, doğrulayıcı faktör analizinin ardından ölçeğin alt boyutlara ait iç tutarlılık katsayıları hesaplanmış ve her alt boyut için Cronbach alfa katsayıları sırasıyla, 0.77 , 0.70 ve 0.67 olarak elde edilmiştir.

Araştırmada ikinci olarak kullanılan ölçme aracı, STEM'e yönelik tutumlarını belirlemek amacıyla Faber ve diğerleri (2013) tarafından geliştirilen ve Yıldırım ve Selvi (2015) tarafından Türkçe 'ye uyarlama çalışması yapılan STEM Tutum Ölçeğinin 21. Yüzyıl Yetenekleri alt boyutu kısmından yararlanılmıştır. Bu ölçekte toplam 11 madde bulunmaktadır. İlgili ölçeğin geçerlik ve güvenirlik çalışmaları Türkçe uyarlama çalışması sonrasın da Yıldırım ve Selvi (2015) tarafından gerçekleştirilmiş olup, 21. yüzyıl yetenekleri alt boyutu için, iç tutarlılık katsayısı 0.89 şeklinde bulunmuştur.

Araştırmada kullanılan ve öğrencilere uygulanan üçüncü ölçek ise Yansıtıcı Düşünme Düzeyi Belirleme ölçeğidir. Ölçek öğrencilere 21. yüzyıl becerilerinin kapsamında bulunan düşünme becerilerinden olan yansıtıcı düşünme düzeylerini belirlemek amacıyla uygulanmıştır. Bu ölçek Başol ve Evin tarafından 2013 yılında geliştirilmiştir. Ölçek tamamı olumlu olan 16 maddeden oluşmaktadır. İlgili ölçekte çalışmada uygulanan diğer ölçekler gibi likert tipinde olup her maddesi için Kesinlikle Katılıyorum, Katılıyorum, Kararsızım, Katılmıorum, Kesinlikle Katılmıyorum şeklinde puanlama yapılmıştır. Yansıtıcı Düşünme Düzeyi Belirleme Ölçeği 'nin geçerlik ve güvenirlik çalışmaları, Barol ve Evin (2013) tarafından yapılmış olup ölçeğin tamamı için Cronbach Alpha katsayısı 0.77 olarak hesaplanmıştır.

\section{İşlem Basamakları}

Çalışmanın yürütülme süreci aşağıda basamaklar halinde verilmiştir.

Sorgulama temelli öğrenme yönteminin 21. yüzyıl becerilerine etkilerinin incelendiği bu araştırmada öncelikle sorgulama temelli öğrenme yöntemi ve 21. yüzyıl becerileri ile ilgili alan yazın taraması yapılmış ve elde edilen çalışmalar incelenmiştir.

Alan yazınla elde edilen çalışmalar incelendikten sonra problem durumu tespit edilmiş ve sorgulama temelli öğrenme yöntemi ile hazırlanan etkinliklerin öğrencilerin 21. yüzyıl becerilerine ve yansıtıcı düşünme becerilerine cinsiyet açısından etkilerine yönelik bir problem durumu oluşturulmuştur.

Problem durumunun oluşturulmasının ardından alan yazından problem durumuna uygun ölçekler incelenmiş ve çalışmada kullanılacak ölçekler belirlenip, her bir ölçek için ilgili kişilerle iletişime geçilip gerekli izinler alınmıştır. 
Samsun ilinde bulunan bir Anadolu lisesinde çalışmanın yürütülmesine karar verilmiştir. İlgili okulda, müdür yardımcısı ve okul biyoloji dersi öğretmeni ile birlikte bir zümre toplantısı yapılmıştır. Zümre toplantısı sonrası öğrenim gören 11. sınıf öğrencileri ile çalışma grupları oluşturulmuştur. Ayrıca 11. sınıf biyoloji dersi sorgulama temelli öğrenime uygun olarak 4 hafta sürecek şekilde ders planı oluşturulmuştur.

2016-2017 eğitim öğretim ikinci döneminde işlenen insanda dolaşım sistemi ve kan grupları ünitesi sorgulama temelli öğrenme yöntemine uygun olarak hazırlanmış ve 4 hafta şeklinde planlanmıştır. Bu bağlamda etkinlikler düzenlenmiştir. Bu etkinlikler ilgili kazanımları ile birlikte tablo 1'de gösterilmiştir.

Tablo 1.

Uygulama Etkinliklerinin Kazanım Dağılımı

\begin{tabular}{ll}
\hline \multicolumn{1}{c}{ Etkinlik adı } & \multicolumn{1}{c}{ Kazanım } \\
\hline Etkinlik 'Elden ele gerçek kalp’ & $\begin{array}{l}\text { Kalp, kan ve damarların yapı, görev ve işleyişini } \\
\text { kavrar. }\end{array}$ \\
Etkinlik 'Deneyini yap, kan & Kan dokusu naklinde doku uyuşmazlığı açıklar. \\
grubunu bul ödülünü kap' & Alyuvar ve akyuvarı tanır. \\
Etkinlik 'Şimdi dolaşım zamanı' & Kan dolaşımını kavrar. \\
& Kalbin çalışmasına etki eden faktörleri araştırır. \\
Etkinlik 'Sorgula, izle, öğren & Kalp krizi, damar tıkanıklığı, kangren, varis gibi \\
etkinliği' & hastalıklarla bağlantı kurar. \\
& Kan yoluyla bulaşan hastalıklara örnekler verir. \\
\hline
\end{tabular}

Uygulamaya başlamadan önce öğrencilere çalışmada kullanılacak olan 21. Yüzyıl Beceri Ölçeği', 'Stem'e Karşı Tutum Ölçeğinin' 21. Yüzyıl Yetenekleri alt boyut ölçeği ve 'Yansitıcı Düşünme Düzeyi Belirleme' ölçeği ön test olarak uygulanmıştır. Uygulama 4 hafta sürmüştür. Ölçekler uygulama sonrasında son test olarak uygulanmıştır. Uygulama sonrasında hem ön testten hem son testten elde edilen veriler SPSS istatistik programı ile analiz edilmiştir.

\section{Verilerin Analizi}

11. sınıfta öğrenim gören öğrenciler ile yürütülen bu çalışmada dört haftalık süreç öncesinde ve sonrasında 21. Yüzyıl Beceri Ölçeği', 'Stem'e Karşı Tutum Ölçeği' 21. Yüzyıl Yetenekleri alt boyut ölçeği ve 'Yansıtıcı Düşünme Düzeyi Belirleme' ölçeği ayrı ayrı uygulanmıştır. Kız ve erkek öğrencilere uygulanan bu ölçeklerden elde edilen veriler SPSS.21 programında analizleri yapılmıştır. Öğrencilerin ölçeklerden aldıkları puanların karşılaştırılması için öncelikle normallik testi uygulanmıştır. Uygulama sonucuna göre verilerin normal dağıldığ tespit edilmiştir. Analizler için parametrik testlerden bağımsız gruplar için t-testinden yararlanılmıştır. 


\section{BULGULAR}

Araştırmanın bu bölümünde, uygulama sürecinde uygulanan 21. Yüzyıl Beceri Ölçeği', 'Stem'e Karşı Tutum Ölçeği' 21. Yüzyıl Yetenekleri alt boyut ölçeği ve 'Yansıtııı Düşünme Düzeyi Belirleme' ölçeklerinden elde edilen verilerin SPSS istatistik programı ile analizlerinin yapılmasının ardından ortaya çıkan bulgular ve bu bulgulara ait yorumlara yer verilmiştir.

Tablo 2.

Öğrencilerin Ölçeklerden Aldıkları Puanlara Ait Tek Grup Kolmogorov-Smirnov Testi Sonuçları

\begin{tabular}{lcccccccc}
\hline \multirow{2}{*}{ Uygulanan Ölçekler } & \multicolumn{4}{c}{ Ön test sonuçları } & \multicolumn{5}{c}{ Son test sonuçları } \\
\cline { 2 - 9 } & $\mathbf{N}$ & $\overline{\mathbf{X}}$ & $\mathbf{S}$ & $\mathbf{p}$ & $\mathbf{N}$ & $\overline{\mathbf{X}}$ & $\mathbf{S}$ & $\mathbf{p}$ \\
\hline Yansıtıcı düşünme ölçeği & 45 & 72,74 & 13,71 & 0,40 & 45 & 81,75 & 1,81 & 0,16 \\
21. yüzyıl beceri ölçeği & 45 & 75,21 & 19,43 & 0,62 & 45 & 79,63 & 17,01 & 0,20 \\
21. yüzyıl alt boyut ölçeği & 45 & 26,93 & 6,03 & 0,25 & 45 & 30,45 & 1,92 & 0,53 \\
\hline
\end{tabular}

Tablo 2 incelendiğinde, gruplarının her ölçek için bütün test puanlarının normal dağılım gösterdiği görülmektedir ( $\mathrm{p}>$.05). Puanları normal dağılım göstermesinden dolayı analizler için her üç ölçek için de parametrik testlerin kullanılabileceği uygun görülmektedir. İlk olarak öğrencilere 21. Yüzyıl beceri ölçeği ön test olarak uygulanmış ve elde edilen veriler t-testi ile karşılaştırılmış ve Tablo 3'te sunulmuştur.

Tablo 3.

Öğrencilerin Cinsiyet Açısından 21. Yüzyıl Beceri Ölçeği Ön Test Verilerine Ait t-Testi Sonuçları

\begin{tabular}{lcccccc}
\hline Gruplar & $\mathbf{N}$ & $\overline{\mathbf{X}}$ & $\mathbf{S}$ & $\mathbf{s d}$ & $\mathbf{t}$ & $\mathbf{p}$ \\
\hline Kız öğrenci grubu & 24 & 128,54 & 15,42 & 43 & 0,96 & 0,33 \\
Erkek öğrenci grubu & 21 & 123,95 & 16,31 & & & \\
\hline
\end{tabular}

Tablo 3 incelendiğinde, 21. yüzyıl beceri ölçeği ön test sonuçlarına göre p değerinin 0,33 olarak bulunduğu görülmektedir. Bu değer $p$ için anlamlılık değeri olan 0,05 ten büyük olduğu için iki grup arasında anlamlı fark yoktur yorumu yapılabilir. Yani bu sonuca göre cinsiyet faktörüne göre öğrencilerin uygulama öncesinde 21. Yüzyıl becerilerinin birbirine denk düzeyde olduğu kabul edilebilir. 21. Yüzyıl becerileri ön test verileri incelendiğinde kız öğrencilerinin ortalamasının 128,54 şeklinde, erkek öğrencilerin ortalamasının ise 123,95 olduğu tespit edilmiştir. Buna göre kız öğrencilerin uygulama öncesindeki 21. Yüzyıl becerilerinin erkeklerden daha yüksek olduğu ancak arlarında anlamlı farklılığın olmadığı ifade edilebilir. Öğrencilere ikinci olarak STEM'e Karşı Tutum Ölçeğine ait 21. Yüzyıl Yetenekleri alt boyut ölçeği uygulanmış ve elde edilen verilere ait t-testi sonuçları Tablo 4 'te verilmiştir. 
Tablo 4.

Öğrencilerin Cinsiyet Açısından 21. Yüzyıl Yetenekleri Alt Boyut Ölçeği Ön Test Verilerine Ait t-Testi Sonuçları

\begin{tabular}{lcccccc}
\hline Gruplar & $\mathbf{N}$ & $\overline{\mathbf{X}}$ & $\mathbf{S}$ & $\mathbf{s d}$ & $\mathbf{t}$ & $\mathbf{p}$ \\
\hline Kız öğrenci grubu & 24 & 42,50 & 5,63 & 43 & $-0,91$ & 0,36 \\
Erkek öğrenci grubu & 21 & 44,19 & 6,73 & & & \\
\hline
\end{tabular}

Tablo 4 incelendiğinde, STEM Tutum Ölçeğinin 21. yüzyıl yetenekleri alt boyutu ön test sonuçlarına göre $p$ değeri 0,36 olarak tespit edilmiştir. Bu değer $p$ için anlamlılık değeri olan 0,05 ten büyük olduğu için iki grup arasında anlamlı fark yoktur yorumu yapılabilir. Yani bu bulguya göre STEM Tutum Ölçeğinin 21. Yüzyıl Yetenekleri alt boyutu ölçeğine göre cinsiyet faktörüne göre öğrencilerin birbirine denk olduğu kabul edilebilir. Cinsiyet açısından öğrencilerin ön test sonuçlarının göre aritmetik ortalamalarına bakıldığında ise kız öğrencilerin 42,50 ortalamaya sahip olduğu, erkek öğrencilerin ise 44,19 ortalamaya sahip olduğu belirlenmiştir. Öğrencilere son olarak Yansıtıcı Düşünme Düzeyi Belirleme Ölçeği ön test olarak uygulanmış ve elde edilen veriler Tablo $5^{\prime}$ te sunulmuştur.

Tablo 5.

Öğrencilerin Yansıtıcı Düşünme Düzeyi Ölçeği Ön Test Verilerinin Cinsiyet Açısından t-Testi Sonuçları

\begin{tabular}{lcccccc}
\hline Gruplar & $\mathbf{N}$ & $\overline{\mathbf{X}}$ & $\mathbf{S}$ & $\mathbf{s d}$ & $\mathbf{t}$ & $\mathbf{p}$ \\
\hline Kiz öğrenci grubu & 24 & 56,33 & 7,20 & 43 & 1,64 & 0,107 \\
Erkek öğrenci grubu & 21 & 52,71 & 7,52 & & & \\
\hline
\end{tabular}

Tablo 5 'teki yansıtıcı düşünme düzeyi belirleme ölçeği ön test sonuçlarına bakıldığında, $p$ değerinin 0,107 olarak belirlenmiştir. Bu değer p için anlamlılık değeri olan 0,05 ten büyük olduğu için iki grup arasında anlamlı fark yoktur yorumu yapılabilir. Yani uygulama öncesinde yansıtıcı düşünme düzeyi ölçeğine göre cinsiyet faktörüne göre öğrenciler birbirine denktir. Kız öğrencilerin ortalamaları 56,33, erkek öğrencilerin ortalaması ise 52,71 olarak tespit edilmiştir. Araştırma kapsamında hazırlanan etkinlikler yapıldıktan sonra öğrencilere tüm veri toplama araçları son test olarak uygulanmıştır. İlk olarak öğrencilere son test olarak uygulanan 21. Yüzyıl Beceri Ölçeğine ait analiz sonuçları Tablo 6' da sunulmuştur.

Tablo 6.

Öğrencilerin Cinsiyet Açısından 21. Yüzyıl Beceri Ölçeği Son Test Verilerine Ait T-Testi Sonuçları

\begin{tabular}{lcccccc}
\hline Gruplar & $\mathbf{N}$ & $\overline{\mathbf{X}}$ & $\mathbf{S}$ & $\mathbf{s d}$ & $\mathbf{t}$ & $\mathbf{p}$ \\
\hline Kız öğrenci grubu & 24 & 127,08 & 20,29 & 43 & 0,70 & 0,007 \\
Erkek öğrenci grubu & 21 & 143,09 & 17,47 & & & \\
\hline
\end{tabular}

Tablo 6 incelendiğinde, 21. yüzyıl beceri ölçeği son test sonuçlarına göre p değeri 0,005 olarak tespit edilmiştir. Bu değer p değeri için anlamlılık değeri olan 0,05 ten küçük olduğundan 
dolayı iki grup arasında anlamlı fark söz konusudur. Bu farkın hangi öğrenciler lehine olduğunu tespit etmek için cinsiyet faktörüne göre öğrencilerin aritmetik ortalamalarına bakılmalıdır. 21. Yüzyıl becerileri son test verilerine göre kız öğrencilerinin ortalamasının 127,08 şeklinde, erkek öğrencilerin ortalamasının ise 143,09 olduğu tespit edilmiştir. Buna göre sonucun erkek öğrenciler lehine olduğu görülmektedir. Elde edilen bu bulguya göre erkek öğrencilerin 21. Yüzyıl becerileri puanları etkinlik sonrasında kız öğrencilere oranla daha fazla artığı söylenilebilir. İkinci olarak öğrencilere STEM Tutum Ölçeğinin 21. Yüzyıl Yetenekleri alt boyutu ölçeği son test olarak uygulanmıştır. Elde edilen veriler t-testi ile analiz edilmiş ve Tablo 7 olarak aşağıda verilmiştir.

Tablo 7.

Öğrencilerin Cinsiyet Açısından 21. Yüzyıl Alt Boyut Ölçeği Son Test Verilerine Ait t-Testi Sonuçlar

\begin{tabular}{lcccccc}
\hline Gruplar & $\mathbf{N}$ & $\overline{\mathbf{X}}$ & $\mathbf{S}$ & $\mathbf{s d}$ & $\mathbf{t}$ & $\mathbf{p}$ \\
\hline Kız öğrenci grubu & 24 & 41,50 & 7,28 & 43 & 0,94 & 0,005 \\
Erkek öğrenci grubu & 21 & 47,42 & 6,12 & & & \\
\hline
\end{tabular}

Tablo 7 incelendiğinde, STEM Tutum Ölçeğinin 21. Yüzyıl Yetenekleri alt boyutu son test verilerine göre $p$ değeri 0,005 olarak tespit edilmiştir. Bu değer $p$ değeri için anlamlılık değeri olan 0,05 ten küçük olduğundan dolayı iki grup arasında anlamlı fark söz konusudur. Bu farkın hangi öğrenciler lehine olduğunu tespit etmek için cinsiyet faktörüne göre öğrencilerin aritmetik ortalamalarına bakıldığında kız öğrencilerinin ortalamasının 41,50 şeklinde, erkek öğrencilerin ortalamasının ise 47,42 şeklinde olduğu tespit edilmiştir. Bu veriler doğrultusunda sonucun erkekler lehine olduğu görülmektedir. Son olarak öğrencilere yansıtıcı düşünme düzeyi ölçeği son test olarak uygulanmış ve veriler t-testi ile analiz edilerek Tablo 8 'de sunulmuştur.

Tablo 8.

Öğrencilerin Cinsiyet Açısından Yansıtıcı Düşünme Düzeyi Ölçeği Son Test Verilerine Ait t-Testi Sonuçları

\begin{tabular}{lcccccc}
\hline Gruplar & $\mathbf{N}$ & $\overline{\mathbf{X}}$ & $\mathbf{S}$ & $\mathbf{s d}$ & $\mathbf{t}$ & $\mathbf{p}$ \\
\hline Kız öğrenci grubu & 24 & 56,62 & 11,60 & 43 & 0,35 & 0,013 \\
Erkek öğrenci grubu & 21 & 65,47 & 11,30 & & &
\end{tabular}

Tablo 8 incelendiğinde, Yansıtıcı düşünme düzeyi belirleme ölçeği son test verilerine göre p değeri 0,013 olarak tespit edilmiştir. Bu değer p için anlamlılık değeri olan 0,05 ten küçük olduğundan dolayı iki grup arasında anlamlı fark söz konusudur. Bu farkın hangi öğrenciler lehine olduğunu tespit etmek için cinsiyet faktörüne göre öğrencilerin aritmetik ortalamalarına bakıldığında, kız öğrencilerinin ortalamasının 56,62 olarak, erkek öğrencilerin ortalamasının ise 65,47 olarak bulunmuştur. Bu sonuçlar doğrultusunda sonucun erkekler lehine olduğu söylenebilir. 


\section{TARTIŞMA VE SONUÇ}

Sorgulama temelli öğrenme yönteminin cinsiyet faktörüne göre öğrencilerin 21. Yüzyıl becerilerine ve Yansıtıcı düşünme düzeylerine etkisinin incelendiği bu çalışmada, öğrencilerle sorgulama temelli etkinlikler tasarlanarak dersler yürütülmüş ve bu bağlamda çeşitli ölçekler uygulanmıştır. Ön test ve son test olarak uygulanan bu ölçeklerden elde edilen veriler analiz edilmiştir. Analiz sonucunda ortaya çıkan bulgulara göre ön test sonuçlarında kız ve erkek öğrencilerin her üç ölçek açısından anlamlı fark bulunamamıştır. Bu sonuç göstermektedir ki uygulama öncesinde cinsiyet faktörüne göre öğrencilerin her üç ölçekten aldıkları puanlar birbirine denktir. Ancak sorgulama temelli etkinlikler sonrasında son test olarak uygulanan ölçeklerden elde edilen veriler incelendiğinde ise, erkek öğrencilerin puanları ile kız öğrencilerin puanları arasında her üç ölçek için de anlamlı farklılık tespit edilmiştir. Bu farkı hangi gruptan kaynakladığını tespit etmek için öğrenci beceri ortalama puanları incelenmiş ve erkek öğrencilerin ortalamalarının kız öğrencilerinin ortalamalarından yüksek olduğu belirlenmiştir. Bu fark erkek öğrenciler lehinedir.

Öğrencilerinin yansıtıcı düşünme ölçeği ön test ve son test puanlarının cinsiyet değişkeni açısından karşılaştırıldığında, yapılan analiz sonuçları incelendiğinde cinsiyet faktörüne göre öğrenciler yansıtıcı düşünme düzeyi ön test sonuçlarına göre birbirine denk düzeydeyken, son test puanlarına göre anlamlı bir şekilde farklılaşmıştır. İki grubun puanlarının ortalaması incelendiğinde, erkek öğrencilerin ortalamasının kız öğrencilerin ortalamasından yüksek olduğu saptanmıştır. İki grup arasında ki bu fark erkek öğrenciler lehine olduğu belirlenmiştir.

Alan yazın incelendiğinde, 21. yüzyıl becerileri ile ilgili deneysel çalışma sayısı oldukça az sayıda olup daha öğrencilerin var olan durumlarının anlık ölçümlerin yapıldığı tarama türü çalışmaların olduğu görülmektedir. Bunun yanında yaptığımız çalışmada olduğu gibi 21. yüzyıl becerilerini cinsiyet değişkeni açısından değerlendirildiği çalışmaların da alan yazında az sayıda olduğu görülmektedir. Bu araştırmada, 21. yüzyıl becerilerinin cinsiyet değişkenine göre incelemesi yapılmış ve erkek öğrenciler lehine bir sonuçlar elde edilmiştir. Ancak, Gülen (2013) yaptığı çalışmada öğretmen adaylarının 21. yüzyıl becerileri öz-yeterlik algılarının öğretmen adaylarının cinsiyetine göre değiştiği, kadın öğrenciler lehine anlamlı farklılık olduğu tespit edilmiştir. Aynı şekilde Karakaş (2015) kız öğrencilerin 21. yüzyıl becerilerinin erkek öğrencilere göre daha yüksek olduğu sonucuna ulaşmışlardır. Şişman, Aypay, Acat ve Karadağ (2010), TIMSS 2007 Türkiye ulusal raporu hazırlamışlardır. Bu rapora göre, TIMSS 2007 sınavına Türkiye'den katılan öğrenciler arasında kız öğrencilerinin başarılarının yüksek olduğunu tespit etmişlerdir. Fen başarıları yüksek olan kız öğrencilerin, erkek öğrencilere göre 21.yüzyıl becerilerine yönelik daha olumlu tutum geliştirdikleri tespit edilmiştir. Murat (2018) öğretmen adayları ile yürüttüğü çalışmadan 21. yüzyıl becerilerini cinsiyet değişkenine göre incelediğinde 
kız öğrencilerin erkek öğrencilere göre yüksek bir ortalamaya sahip olduğunu belirtmiştir. Başar (2018) öğretmen adayları ile gerçekleştirdiği çalışmasında 21. yüzyıl becerileri öz-yeterlik algılarının öğretmen adaylarının cinsiyetine göre değiştiği ve kadın öğrenciler lehine anlamlı farklılık olduğu tespit etmiştir. Özçakır Sümen ve Çalışıcı (2017) yapmış oldukları bir çalışmada ortaokul öğrencilerinin 21. yüzyıl becerileri irdelenmiş ve çalışma sonucunda kız öğrencilerin 21. yüzyıl becerilerinin erkek öğrencilerden daha yüksek olduğu tespit edilmiştir. 21. yüzyıl becerileri ile ilgili alan yazından ulaşılan sonuçlara bakıldığında, alan yazındaki araştırma sonuçları daha çok kız öğrencilerin erkek öğrencilere oranla 21. Yüzyıl becerilerinin daha fazla olduğuna yönelik sonuçlar bulunmaktadır. Çalışmamızın ön test sonuçlarında kız öğrenciler erkek öğrencilere oranla daha fazla puan almışlardır. Ön test sonuç alan yazın da yapılan tek ölçümlerle yapılan ve var olan durumu tespit etmeye yönelik çalışmaların sonuçları ile uyum göstermektedir. Ancak alan yazından farklı olarak bu çalışmada öğrencilere sorgulama temelli öğrenme yöntemine göre hazırlan etkinlikler uygulanmış ve deneysel bir çalışma yapılmıştır. Deneysel çalışmanın sonucunda ön testte anlamlı farklılık olmamasına rağmen kız öğrencilerden düşük puan alan erkek öğrenciler, son test puanlarında kız öğrencilere oranla 21. Yüzyıl becerileri ölçeğinden daha yüksek puan almışlardır. Öğrencilerin cinsiyet faktörüne göre son test ortalama puanları arasında erkekler lehine anlamlı bir farklılık olduğu tespit edilmiştir. Bu bulguya göre başlangıçta kız öğrencilerden daha düşük puan alan erkek öğrencilerin sorgulama temelli etkinliklerin uygulanması neticesinde 21. yüzyıl becerilerinin gelişiminin kız öğrencilere göre daha fazla olduğu ifade edilebilir.

Yansıtıcı düşünme düzeyinin cinsiyete göre değerlendirildiği diğer çalışmalara bakıldığında Kuzu'nun (2015) fen bilgisi öğretmenleri ile yaptığı araştırmada öğretmenlerinin cinsiyeti, kıdemleri ve mezun oldukları okul gibi değişkenler ile yansıtıcı düşünme becerilerini kullanma düzeyi arasında genel olarak anlamlı bir fark tespit edilememiştir. Alan yazın incelemelerine göre cinsiyet değişkenine göre yapılan çalışmalarda farklı öğretim yöntemlerinin bir etkisi olmadığı sonucu fark edilmiştir. İnönü (2006), Ergüven (2011) tarafından yapılan yüksek lisans çalışması, Dalgıç (2011) tarafından yapılan doktora çalışması, Şahin (2011), Tümkaya ve Hurioğlu (2013) tarafından yapılan çalışmada cinsiyet değişkeni ile öğrenme yöntemi arasında bir ilişki tespit edilmemiştir. Bu tespitler, bu araştırmadaki yansıtııı düşünme düzeyleri puanları açısından farklıdır. Aynı şekilde; Karadağ (2010), Urhan (2013) tarafından yapılan yüksek lisans çalışma ile Duban ve Yelken (2010), Aydın ve Çelik (2013), Demiralp ve Kazu (2017) tarafından yapılan çalışmada cinsiyet değişkeni ile düşünme arasında anlamlı bir ilişki olduğunu ve bu ilişkiye göre kadınların erkeklerden daha fazla yansıtıcı düşünme eğilimi gösterdiğini iddia etmektedirler. Bu çalışmaya benzer şekilde, Yetim (2014) cinsiyet değişkenine göre yansitıcı düşünme düzeylerini incelemiş ve kavrama alt boyutun da ve yansıtma alt boyutlarında erkeklerin lehine anlamlı fark bulmuştur. Alan yazın incelemesi sonucuna göre yansitıcı 
düşünme düzeyi ile ilgili çalışmaların hem kız öğrenciler hem erkek öğrenciler lehine sonuçlandığı çalışmalar bulunmaktadır. Cinsiyet faktörüne göre, öğrencilerin son test ortalamalarına bakıldığın da erkekler lehine anlamlı bir farklılık olduğu tespit edilmiştir. Bu sonuclara göre; kız öğrencilerden daha düşük puan alan erkek öğrencilerin, sorgulama temelli etkinliklerin uygulanması sonrasın da Yansıtıı düşünme düzeylerini daha fazla geliştirdiği ifade edilebilir.

\section{ÖNERILER}

$\mathrm{Bu}$ çalışma süresince ulaşılan bulguların sonucuna göre çalışma için birkaç öneri siralanabilir:

1. Bu araştırma, lise düzeyindeki öğrenciler ile gerçekleştirilmiştir. Sorgulama temelli öğrenme yönteminin uygulandığ 1 bu araştırma ilkokul, ortaokul ve üniversite düzeyindeki öğrencileri kapsayacak şekilde de yapılabilir.

2. Son yıllarda yapılan çalışmalar incelendiğinde; çalışmalar 21. yüzyıl becerilerini tanıma, bu becerileri belirleme şeklindedir. Farklı öğretim yöntem ve tekniklerinin 21. yüzyıl becerileri üzerine etkilerinin incelendiği deneysel çalışmalar yapılabilir.

3. Bu çalışmada 21. yüzyıl becerilerinden yansıtıcı düşünme düzeyine ait ölçümler yapılmıştır. Başka araştırmalarda yansıtıcı düşünme düzeyi yerine eleştirel düşünme veya yaratıcı düşünme becerilerine ait testler de kullanılabilir.

4. Bu çalışma, nicel yöntem kullanılarak elde edilen verilerle yapılmıştır Araştırma bulguları, nitel araştırma yöntemleri ile elde edilecek verilerle desteklenebilir veya 21. yüzyıl becerileri nitel verilerle daha iyi irdelenebilir.

\section{KAYNAKLAR}

Aydın, M., \& Çelik, T. (2013). Sosyal bilgiler öğretmen adaylarının yansıtıcı düşünme becerilerinin bazı değişkenler açısından incelenmesi. Pamukkale Üniversitesi Eğitim Fakültesi Dergisi, 34(34), 169-131.

Başar, S. (2018). Fen bilimleri öğretmen adaylarının fende matematiğin kullanımına yönelik özyeterlik inançları, 21. yy becerileri ve aralarındaki ilişkinin incelenmesi. Yayınlanmamış Yüksek Lisans Tezi, Hacettepe Üniversitesi, Ankara.

Başaran, M. (2005). Sınıf öğretmeni adaylarının bilgi okuryazarlıklarının değerlendirilmesi. Gazi Üniversitesi Gazi Eğitim Dergisi, 25(3), 163-177.

Başol, G., \& Evin-Gencel, İ. (2013). Yansıtıcı düşünme düzeyini belirleme ölçeği: Geçerlik ve güvenirlik çalışması. Kuram ve Uygulamada Eğitim Bilimleri. 13(2), 929-946. 
Colwill, I., \& Gallagher, C. (2007). Developing a curriculum for the twenty-first century: the experiences of England and Northern Ireland. Prospects. 37(4), 411-425.

Cüceloğlu, D. (1995). İyi düşün doğru karar ver. İstanbul: Sistem Yayıncılık.

Çakıcı, Y. (2007). Bilimsel araştırma yaklaşımları. (Ed: Durmuş Ekiz, 2007, s. 45-60). İstanbul: Lisans Yayıncilik.

Dalgıç, G. (2011). Okul yöneticilerinin yansıtıcı düşünme beceri ve uygulamalarının incelenmesi: İstanbul ve Kopenhag örneği. Yayınlanmamış Doktora Tezi. Marmara Üniversitesi, İstanbul.

Demiralp, D., \& Kazu, H. (2017). Öğretmen adayları için kişisel-mesleki yetkinlikler algı ölçeği: geçerlik ve güvenirlik çalışması. Kuram ve Uygulamada Egitim Yönetimi Dergisi, 23(3), 425464.

Duban, N., \& Yelken, T. Y. (2010). Öğretmen adaylarının yansıtıcı düşünme eğilimleri ve yansıtıcı öğretmen özellikleriyle ilgili görüşleri. Çukurova Üniversitesi Sosyal Bilimler Enstitüsü Dergisi, 19(2), 343-360.

Ekici, G. (2001). Biyoloji öğretmenlerinin öğretim yöntemleri konusundaki teorik bilgi yeterliliklerinin incelenmesi. Çă̆daş Ĕ̆itim, 274, 40-46.

Ergüven, S. (2011). Öğretmenlerin yansıtıcı düşünme becerilerinin çeşitli değişkenler açısından incelenmesi. Yayınlanmamış Yüksek Lisans Tezi. Niğde Üniversitesi, Niğde.

Eryılmaz, S., \& Ulusoy, Ç. (2015). 21. yüzyıl becerileri işığında fatih projesi değerlendirmesi. Gazi Üniversitesi Ĕ̆itim Fakültesi Dergisi, 2(35), 209-229.

Faber, M., Unfried, A., Wiebe, E. N., Corn, J., Townsend, L. W., \& Collins, T. L. (2013). Student attitudes toward STEM: The development of upper elementary school and middle/high school student surveys. In the Proceedings of the 120th American Society of Engineering Education Conference. 2013, Amerika

International Technology Education Association (2003). Advancing excellence in technological literacy: Student assessment, professional development, and program standards. Reston, VA: Author.

Gülen Ş. B. (2013) Ortaokul öğrencilerinin 21. yüzyıl öğrenme becerileri ve bilişim teknolojileri ile destekleme düzeylerinin cinsiyet ve sinıf seviyesine göre incelenmesi. Yayınlanmamış Yüksek Lisans Tezi, Gazi Üniversitesi, Ankara.

Kalyoncu, A. T. (2012). Yirmibirinci yüzyılda öğrencilerin sahip olması gereken bazı temel becerilere ilişkin yönetici ve öğretmen görüşleri. Yayınlanmamış Yüksek Lisans Tezi, Yeditepe Üniversitesi, İstanbul.

Kang, M., Kim, B., Kim, B., \& You, H. (2012). Developing an instrument to measure 21st century skills for elementary students. The Korean Journal of Eductional Methodolocy Studies, 25(2).

Karadağ M. (2010). Sosyal Bilgiler öğretmenlerinin yansıtıcı düşünme düzeylerinin incelenmesi: Şanlıurfa ili örneği. Yayınlanmamış Yüksek Lisans Tezi, Çukurova Üniversitesi, Adana. 
Karakaş, M., M. (2015). Ortaokul sekizinci sını öğrencilerinin fen bilimlerine yönelik 21. yüzyıl beceri düzeylerinin ölçülmesi. Yayınlanmamış Yüksek Lisans Tezi. Osman Gazi Üniversitesi Eğitim Bilimleri Enstitüsü, Eskişehir.

Karakoyun, F. (2014). Çevrimiçi ortamda oluşturulan dijital öyküleme etkinliklerine ilişkin öğretmen adayları ve ilköğretim öğrencilerinin görüşlerinin incelenmesi. Yayınlanmamış Doktora Tezi, Anadolu Üniversitesi, Eğitim Bilimleri Enstitüsü, Eskişehir.

Karakuş, M. (2011). Eğitim ve yaratıcılık. Eğitim ve Bilim Dergisi, 26(119), 3-7.

Karamustafaoğlu, S., \& Havuz, A. C. (2016). Araştırma sorgulamaya dayalı öğrenme ve etkililiği. International Journal of Assessment Tools in Education, 3(1), 40-54.

Korkut, F. (2002). Lise öğrencilerinin problem çözme becerileri. Hacettepe Üniversitesi Eğitim Fakültesi Dergisi, 22, 177-184.

Kuzu, S. (2015). Fen bilgisi öğretmenlerinin yansıtıcı düşünmeye ilişkin görüşlerinin değerlendirilmesi: Şırnak ili örneği. Yayınlanmamış Yüksek lisans Tezi. Dicle Üniversitesi, Diyarbakır.

Llewellyn, D. (2005). Teaching high school science through inquiry: A case study approach. Corwin Press.

Milli Eğitim Bakanlığı. (2017). Ortaokul fen bilimleri dersi (3, 4, 5, 6, 7 ve 8. stnıflar) öğretim programı. Ankara: Talim ve Terbiye Kurulu Başkanlığı. Ankara: Talim ve Terbiye Kurulu Başkanlığı.

Milli Eğitim Bakanlığı. (2018). Ortaokul fen bilimleri dersi (3, 4, 5, 6, 7 ve 8. sinıflar) öğretim programı. Talim ve Terbiye Kurulu Başkanlığı. Ankara: Talim ve Terbiye Kurulu Başkanlığı.

Murat, A. (2018). Fen bilgisi öğretmen adaylarmmn 21. yüzyll becerileri yeterlik algılan ile STEM'e yönelik tutumlarının incelenmesi. Yayınlanmamış Yüksek Lisans Tezi, Fırat Üniversitesi Eğitim Bilimleri Enstitüsü, Elazı̆̆.

Özçakır Sümen, Ö., \& Çalışıcı, H. (2017). Examining the 21st century skills of secondary school students: a mixed method study. Journal of Education \& Social Policy, 4(4), 92-100.

Özden, Y. (2014). Öğrenme ve öğretme (12 b.). Ankara: Pegem Akademi.

Partnership for 21st Century Learning. (2015). P21 Framework definitions. http://www.p21.org/storage/documents/docs/P21_Framework_Definitions_New_Log o_2015.pdf. Erişim Tarihi: 04.04.2019

Sarıoğlan, A. B., \& Fatih, D. (2017). Fen bilimleri dersinde öğrencilerin araştırma yaklaşımları ile ilgili fikirlerinin belirlenmesine yönelik bir araştırma. Eğitim ve Öğretim Araştırmalarn Dergisi, 6(3),11-22.

Şişman, M., Acat, B., Aypay, A., \& Karadağ, E. (2011). Uluslararası fen ve matematik öğrenci başarisi sinavi (trends in international mathematics and science study/TIMSS) Türkiye Ulusal Raporu. Ankara: MEB.

Tan, M., \& Temiz, K. (2003). Fen öğretiminde bilimsel süreç becerilerinin yeri ve önemi. Pamukkale Üniversitesi Ĕ̆itim Fakültesi Dergisi, 13(13), 89-101. 
Tümkaya, S., \& Hurioğlu, A. G. L. (2013). Öğretim elemanlarının yansıtıcı düşünme eğilimleri. Çukurova Üniversitesi Sosyal Bilimler Enstitüsü Dergisi, 22(1), 243-256.

Tüysüz, M., Şardă̆, M., \& Durukan, A. (2017). Araştırma-sorgulama temelli öğrenme yaklaşımının fen bilimleri öğretmen adaylarının analitik kimya öğrenimine etkisi. Yüzüncü Yıl Üniversitesi Eğitim Fakültesi Dergisi, 14(1), 1657-1696.

Urhan, İ. (2013). Türkçe öğretmeni adaylarının yansıtıcı düşünme ile öğretmen öz yeterlik algısı arasındaki ilişkisinin incelenmesi: Niğde üniversitesi örneği. Yayınlanmamış Yüksek Lisans Tezi, Niğde Üniversitesi, Niğde.

Üstünoğlu, E. (2006). Üst düzey düşünme becerilerini geliştirmede bilişsel soruların rolü. Çağdaş Eğitim Dergisi, 31(331), 17-24.

Yetim, N. (2014). Ortaöğretim öğrencilerinde yansıtıcı düşünme becerisi, akademik stres düzeyi ve yabancı dil dersi akademik başarı ilişkisi. Yayınlanmamış Yüksek Lisans Tezi, Gaziosmanpaşa Üniversitesi, İstanbul.

Yıldırım, B., \& Selvi, M. (2015). Adaptation of STEM attitude scale to Turkish. Turkish Studies, 10(3), 1107-1120.

Etik Kurul Kararı: Ondokuz Üniversitesi Sosyal ve Beşeri Bilimler Etik Kurulu Onay Belgesi 28.02.2017 tarihinde 2017/30 karar sayısı ile alınmış ve araştırma etik yönden uygun bulunmuştur. 